\title{
Analisis Penerapan Program Laku Pandai pada PT XYZ
}

\author{
Putu Ayu Sruti Permata Sari ${ }^{1}$, Budi Frensidy ${ }^{2}$ \\ Magister Akuntansi, Fakultas Ekonomi dan Bisnis, Universitas Indonesia, Jakarta, Indonesia ${ }^{1}$ \\ Magister Akuntansi, Fakultas Ekonomi dan Bisnis, Universitas Indonesia, Jakarta, Indonesia²
}

\begin{abstract}
Abtract. Laku pandai is financial inclusion and financial literacy program launched by the government so that more people can do financial services. PT XYZ's laku pandai customer realization was not as targeted in 2018. How is the laku pandai program implemented at PT XYZ? Why was PT XYZ's laku pandai customer target not achieved? Based on this research problem, The purpose of this study was to evaluate the implementation of laku pandai at PT XYZ and analyze the factors that caused PT XYZ's laku pandai customer target not achieved. The research method used is a qualitative method. The data used are primary data. The data analysis used is descriptive qualitative analysis. The findings in this study indicate that the target of laku pandai customers not achieved because PT XYZ uses a centralized structure. The account opening process is still not integrated. PT XYZ's laku pandai feature is still limited to deposits, withdrawals, and transfers between the laku pandai account. In addition, PT XYZ lacks experience in handling the laku pandai market segment. The process of opening accounts requires more time than the service level agreement.
\end{abstract}

Keywords. Laku pandai, financial inclusion, financial literation, branchless banking, bank.

\begin{abstract}
Abstrak. Laku pandai merupakan program inklusi keuangan dan literasi keuangan yang diusung pemerintah agar lebih banyak masyarakat yang dapat tersentuh jasa keuangan. Realisasi nasabah laku pandai tahun 2018 PT XYZ tidak sesuai yang ditargetkan. Bagaimana pelaksanaan program laku pandai pada PT XYZ? Mengapa target nasabah PT XYZ tidak tercapai? Berdasarkan permasalahan tersebut, maka tujuan penelitian ini adalah untuk mengevaluasi pelaksanaan laku pandai di PT XYZ dan menganalisa faktor-faktor yang menyebabkan target nasabah laku pandai tidak tercapai pada tahun 2018. Metode penelitian dalam penelitian ini menggunakan metode kualitatif. Data yang digunakan adalah data primer. Analisis data pada penelitain ini menggunakan descriptive qualitative analysis. Temuan pada penelitian ini menunjukkan target nasabah laku pandai tidak tercapai karena pelaksanaan laku pandai PT XYZ menggunakan struktur di mana tersentralisasi, masih belum terintegrasi, masih memiliki fitur yang terbatas pada setoran, tarikan, dan transfer antar rekening laku pandai. Selain itu PT XYZ kurang memiliki pengalaman dalam menangani segmen pasar laku pandai, proses pembukaan rekening nasabah laku pandai PT XYZ memerlukan waktu yang melebihi SLA.
\end{abstract}

Kata kunci. laku pandai, inklusi keuangan, literasi keuangan, branchless banking, bank.

Correspondence.putu.ayu76@ui.ac.id, budi.frensidy@ui.ac.id

History of article. Received: April 2019, Revision: Juli 2019, Published: September 2019

\section{PENDAHULUAN}

Indikator suatu negara dapat dikatakan

negara maju atau negara berkembang dapat dilihat pada pertumbuhan ekonomi negara tersebut. Jika pertumbuhan ekonomi dikaitkan dengan struktur keuangan sebuah negara, maka negara penganut sistem keuangan yang bankbased pada tahap awal pengembangan ekonominya lebih baik dari sistem keuangan market-based dalam memobilisasi tabungan dan mengalokasikan modal. Sebaliknya suatu negara yang menganut sistem keuangan market-based menyediakan layanan keuangan yang merangsang inovasi dan pertumbuhan jangka panjang (Levine, 2002). Oleh karena itu, setiap sistem keuangan memiliki kelebihannya masingmasing dalam meningkatkan pertumbuhan ekonomi.

Menurut data pada Bursa Efek Indonesia (BEI), emiten yang tercatat pada BEI sampai 25 Februari 2019 sejumlah 625 perusahaan, dengan kapitalisasi pasar per Desember 2018 sebesar Rp7.023,50 triliun menurut data statistik pasar modal Otoritas Jasa Keuangan. Sedangkan dana pihak ketiga per Desember 2018 mencapai Rp5.630,448 triliun menurut data statistik perbankan Indonesia. Oleh karena itu, tampak Indonesia lebih kepada sistem keuangan bankbased. Walaupun Indonesia lebih ke sistem keuangan bank-based dan pemerintah sudah 
sering mendorong untuk menabung, namun ternyata tidak seluruh masyarakat Indonesia dapat akses terhadap sistem keuangan.

Dalam era globalisasi saat ini, dapat dikatakan hampir seluruh masyarakat telah menggunakan dan memanfaatkan layanan keuangan yang diberikan oleh bank dengan baik. Layanan keuangan yang diberikan oleh bank seperti dalam bentuk produk tabungan, kredit kepemilikan rumah, kredit kepemilikan motor, hingga produk investasi sangat diminati dan dimanfaatkan oleh sebagian masyarakat. Terlebih lagi, semakin berkembangnya zaman dan teknologi membuat kebutuhan dan harapan masyarakat terus mengalami perubahan. Pengetahuan akan jasa keuangan di Indonesia masih belum maksimal dan jauh dari harapan (Bank Indonesia, 2013).

Pemerintah sudah sering mendorong untuk menabung, namun ternyata tidak seluruh masyarakat Indonesia dapat akses terhadap sistem keuangan. Berdasarkan informasi dari Bank Indonesia, didapatkan bahwa pengetahuan akan jasa keuangan di Indonesia masih belum maksimal dan jauh dari harapan (Bank Indonesia, 2013). Sehingga, dibutuhkan upaya maksimal untuk meningkatkan akses terhadap jasa keuangan.

Kebijakan inklusi keuangan dan literasi keuangan diharapkan dapat menjadi solusi atas tantangan jarak dan geografi yang dirasa menyebabkan sebagian masyarakat kurang tersentuh jasa keuangan (Bank Indonesia, 2013). Melalui Bank Indonesia (BI) dan Otoritas Jasa Keuangan (OJK), pemerintah membuat program Layanan Keuangan Digital (LKD) dan Layanan Keuangan Tanpa Kantor dalam Rangka Keuangan Inklusif (laku pandai) untuk mensukseskan program inklusi keuangan dan literasi keuangan tersebut.

\section{Persebaran Agen Laku Pandai TW III/2018}
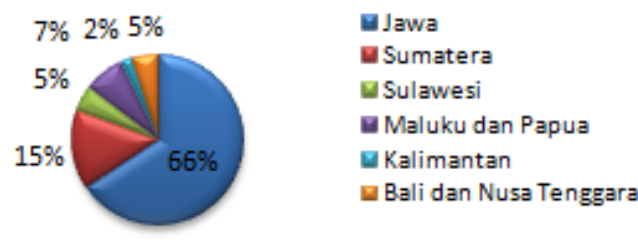

Sumber: Website Otoritas Jasa Keuangan dan diolah oleh penulis

\section{Diagram 1 Persebaran Agen Laku Pandai TWIII/2018}

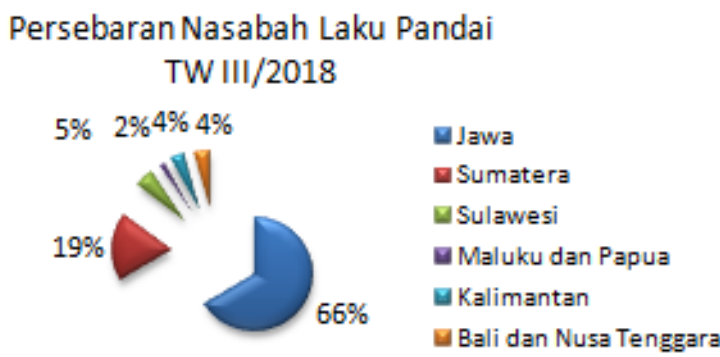

Sumber: Website Otoritas Jasa Keuangan dan diolah oleh penulis

Diagram 2. Persebaran Nasabah Laku Pandai TW III/2018

Berdasarkan diagram 1 dan 2 diatas, dapat dikatakan bahwa dari seluruh nasabah laku pandai yang ada pada Triwulan III 2018 persebaran agen dan nasabah paling banyak berada di Pulau Jawa.

Sebagai salah satu bank penyelenggara laku pandai di Indonesia, PT XYZ juga mendukung program pemerintah terkait inklusi keuangan dan literasi keuangan melalui produk laku pandainya sendiri. Motivasi dilakukannya penelitian ini karena terdapat fenomena perbedaan target dan realisasi nasabah laku pandai pada PT XYZ.

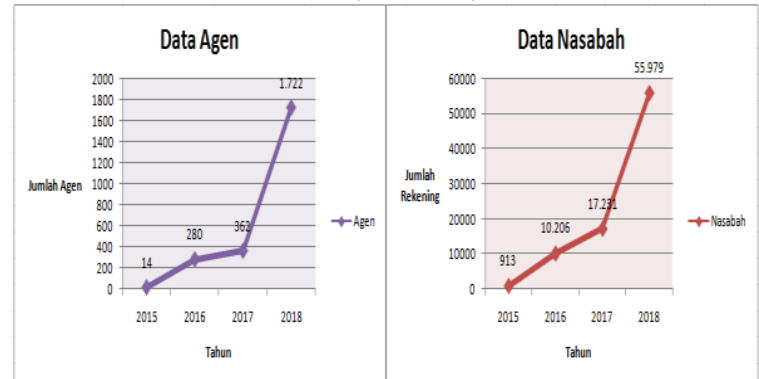

Sumber: PT. XYZ dan diolah oleh penulis.

Grafik 3 Pertumbuhan Agen dan Nasabah

Berdasarkan data agen dan nasabah pada Grafik 3 diatas, sejak dilaksanakannya program laku pandai tahun 2015 terjadi peningkatan agen dan nasabah yang signifikan, terutama pada tahun 2017 ke 2018. Namun, apabila dilihat dari ketersediaan fitur laku pandai pada PT XYZ yang baru sebatas transaksi keuangan dasar (Basic Saving Account), kenaikan nasabah ini tidak sejalan dengan produk yang ditawarkan PT. XYZ yang masih sampai tahap saving, untuk payment, credit, dan insurance masih belum tersedia. 
Berdasarkan data yang didapatkan dari PT XYZ, target nasabah laku pandai adalah 97.500 nasabah, namun realisasi nasabah tahun 2018 adalah 55.979 nasabah.

Berdasarkan latar belakang tersebut, pokok permasalahan dalam penelitian ini adalah, (1) Bagaimana pelaksanaan program laku pandai pada PT XYZ? (2) Mengapa target nasabah PT XYZ tidak tercapai? Berdasarkan pokok permasalahan tersebut, maka tujuan penelitian ini adalah untuk mengevaluasi pelaksanaan laku pandai di PT XYZ dan menganalisa faktor-faktor yang menyebabkan target nasabah laku pandai tidak tercapai pada tahun 2018. Penelitian ini dibatasi hanya untuk mengevaluasi pelaksanaan laku pandai di PT XYZ pada tahun 2018. PT XYZ merupakan perusahaan yang bergerak dalam industri Perbankan.

Menurut Wibowo dan Muharrami (2018), literasi keuangan berpengaruh signifikan positif terhadap investasi pada pasar modal syariah. Menurut Cahyaningrum (2017), laku pandai masih memiliki kendala terkait rendahnya internet dan ketersediaan listrik walaupun secara umum telah baik. Perbankan dengan menggunakan agen menjadi penyaluran yang penting bagi jasa keuangan dalam membantu biaya operasional bank (Kipng'etich et al., 2018). Syaniardi dan Shihab (2016) menyebutkan bahwa branchless banking berbeda dari conventional banking karena yang melakukan pelayanan transaksi perbankan adalah agen, sehingga peran agen sangatlah penting. Shihadeh, Hannon, Guan, Haq, dan Wang, (2018) mengatakan bahwa ada pengaruh signifikan dari adanya inklusi keuangan terhadap kinerja dari suatu bank ketika diukur dengan gross income dan ROA. Inklusi keuangan meningkatkan kinerja bank. Chipeta dan Muthinja (2018) melakukan penelitian untuk melihat hubungan inovasi keuangan melalui model branchless banking dan kinerja keuangan. Hasilnya menunjukkan bahwa inovasi keuangan berkontribusi terhadap kinerja keuangan bank.

Dari penelitian diatas menunjukkan bahwa literasi keuangan dan inklusi keuangan memiliki pengaruh yang positif terhadap investasi pasar modal serta kinerja keuangan, selain itu penelitian sebelumnya membicarakan mengenai kendala Laku pandai serta pentingnya peranan agen. Penelitian kali ini akan di teliti dari segi situasi dan struktur yang mempengaruhi pelaksanaan inklusi keunngan tersebut dengan judul evaluasi pelaksanaan program laku pandai pada PT XYZ. Teori yang diterapkan dalam penelitian ini adalah teori kontijensi.

Penelitian ini adalah penelitian yang menggunakan studi kasus, serta menggunakan metode kualitatif. Data primer berupa wawancara untuk mendapatkan pemahaman mendalam mengenai pelaksanaan Laku pandai pada PT XYZ. Analisa data yang dilakukan menggunakan descriptive qualitative analysis untuk menganalisa wawancara yang telah dilakukan.

Manfaat penelitian dapat berupa untuk pemecahan masalah atau memberi solusi, untuk pengambilan keputusan, untuk evaluasi dan analisis dari keputusan yang dibuat (Ellet, 2007). Oleh karena itu, penelitian ini diharapkan dapat memberikan manfaat sebagai berikut, (1) bagi perusahaan, penelitian ini diharapkan dapat bermanfaaat untuk mengevaluasi dan memberi solusi terhadap penerapan program laku pandai PT XYZ. Semakin efektif pelaksanaan program laku pandai ini tentunya membuat PT XYZ berperan dalam mensukseskan program pemerintah, (2) bagi pemerintah, penelitian ini diharapkan dapat memberikan manfaat kepada pemerintah dalam pembuatan keputusan dan rencana untuk program laku pandai ke depannya serta mengukur efektivitas pelaksanaan program laku pandai tersebut, (3) bagi masyarakat, penelitian ini diharapkan dapat bermanfaat bagi masyarakat yang belum tersentuh jasa keuangan. Dengan efektivitas yang tinggi dan tercapainya target yang ditetapkan maka program laku pandai akan sampai ke seluruh Indonesia dan masyarakat yang belum tersentuh jasa keuangan akan dapat merasakannya.

\section{KERANGKA PENELITIAN \& HIPOTESIS}

\section{Inklusi Keuangan}

Inklusi keuangan merupakan tersedianya akses terhadap jasa keuangan bagi masyarakat, terutama yang belum tersentuh jasa keuangan agar tercapai masyarakat yang lebih sejahtera (Otoritas Jasa Keuangan, 2016). Inklusi keuangan tentu merupakan hal yang penting untuk dilakukan agar masyarakat lebih mudah mendapatkan akses ke dalam layanan perbankan walaupun tanpa bank dan dengan melalui agen.

Terdapat langkah-langkah intervensi dalam inklusi keuangan. Yang pertama adalah kesadaran dari masyarakat. Setelah masyarakat 
memiliki pengetahuan dan kesadaran yang cukup, langkah berikutnya adalah pembayaran, penyimpanan, kredit, dan asuransi (Soejachmoen, 2016). Dengan terlaksananya langkah-langkah ini maka masyarakat akan lebih inklusif dan kesejahteraan dapat meningkat.

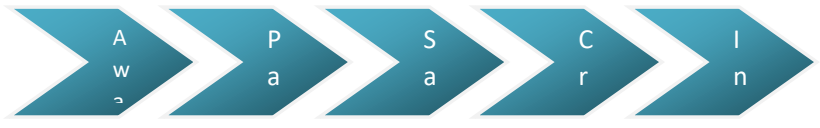

Sumber: Soejachmoen (2016)

Shihadeh, Hannon, Guan, Haq, dan Wang

(2018) mengatakan bahwa ada pengaruh signifikan dari adanya inklusi keuangan terhadap kinerja dari suatu bank ketika diukur dengan gross income dan ROA dan oleh karena itu inklusi keuangan meningkatkan kinerja bank. Selain itu, Chipeta dan Muthinja (2018) melakukan penelitian untuk melihat hubungan inovasi keuangan melalui model branchless banking dan kinerja keuangan menunjukkan bahwa inovasi keuangan berkontribusi terhadap kinerja keuangan bank.

\section{Indikator Keuangan Inklusif}

Menurut Bank Indonesia (2014) harus terdapat indikator atau ukuran kinerja pada perkembangan kegiatan inklusi keuangan. Indikator yang dapat dijadikan ukuran adalah, (a) Ketersediaan atau akses, indikator ketersediaan atau akses digunakan untuk mengukur penggunaan jasa keuangan formal dalam hal keterjangkauan fisik dan harga, (b) Penggunaan, indikator penggunaan digunakan untuk mengukur kemampuan penggunaan aktual produk dan jasa keuangan, (c) Kualitas, indikator kualitas untuk mengukur apakah atribut produk dan jasa keuangan telah memenuhi kebutuhan pelanggan. (d) Kesejahteraan, indikator kesejahteraan digunakan untuk mengukur dampak layanan keuangan terhadap tingkat kehidupan pengguna jasa.

Penelitian sebelumnya menunjukkan inklusi keuangan di Indonesia masih dipengaruhi oleh dimensi aksesibilitas. Dimensi availibilitas dan penggunaan hanya memiliki proporsi yang kecil (Sanjaya, 2016). Belum dapat dilihat bagaimana inklusi keuangan di Indonesia dilihat dari dimensi kualitas dan kesejahteraan.

\section{Literasi Keuangan}

Literasi keuangan adalah suatu pengetahuan yang dimiliki masyarakat untuk dapat meningkatkan pengambilan keputusan sehingga nantinya masyarakat dapat menjadi lebih sejahtera (Otoritas Jasa Keuangan, 2016). Dengan masyarakat yang memiliki pengetahuan tentang jasa keuangan, maka masyarakat tidak lagi menyimpan tabungan dirumahnya namun akan menyimpannya pada bank dan ini akan masuk ke sistem perekononomian negara kita, tentu ini membuat kesejahteraan masyarakat meningkat.

Menurut Wibowo dan Muharrami (2018), literasi keaungan berpengaruh signifikan positif terhadap investasi pada pasar modal syariah. Oleh karena itu, adanya literasi keuangan juga meningkatkan pemahaman masyarakat akan pasar modal.

\section{Laku Pandai}

Laku pandai adalah program pemerintah yang berarti Layangan Keuangan Tanpa Kantor Dalam Rangka Keuangan Inklusif. Laku pandai merupakan program dari Otoritas Jasa Keuangan dalam rangka mendukung inklusi keuangan. Menurut Peraturan Presiden Republik Indonesia (2016) laku pandai adalah suatu program yang dilaksanakan agar masyarakat dapat menikmati layanan perbankan atau layanan keuangan lain dengan bantuan agen dan sarana teknologi informasi yang memadai.

Menurut Cahyaningrum (2017), laku pandai masih memiliki kendala terkait rendahnya internet dan ketersediaan listrik walaupun secara umum telah baik. Perlindungan hukumnya sendiri yaitu kesadaran nasabah untuk menjaga kode sandi, PIN, dan OTP dirasakan juga masih cukup rendah. Selain itu, biaya pulsa tinggi dan terdapat biaya yang ditarik kepada nasabah diluar ketentuan, serta belum terdapat aturan yang mengatur kewajiban agen untuk menjaga kerahasiaan data nasabah dan simpanannya beserta sanksinya.

\section{Bank}

Bank merupakan lembaga intermediasi keuangan, di mana tujuan didirikannya adalah untuk menerima simpanan uang, meminjamkan uang, dan menerbitkan promes. Dengan kata lain, bank merupakan lembaga yang menyediakan jasa perbankan dan jasa keuangan (Abdullah, 2014). 
Bank merupakan lembaga yang digunakan untuk melakukan penyimpanan uang, namun masih saja banyak masyarakat terutama yang di desa yang belum teredukasi tentang bank. Untuk itu maka bank juga harus melakulan inklusi keuangan dan literasi keuangan untuk seluruh masyarakat Indonesia agar tercapainya peningkatan kesejahteraan.

Penelitian terdahulu lainnya yang digunakan sebagai pembanding dalam penelitian ini adalah studi yang menyatakan bahwa perbankan dengan menggunakan agen menjadi penyaluran yang penting bagi jasa keuangan dalam membantu biaya operasional bank (Kipng'etich et al., 2018). Syaniardi dan Shihab (2016) menyebutkan bahwa branchless banking berbeda dari conventional banking karena yang melakukan pelayanan transaksi perbankan adalah agen, sehingga peran agen sangatlah penting.

Penelitian di atas menunjukkan bahwa pelaksanaan inklusi keuangan melalui branchless banking memberikan pengaruh yang baik bagi perusahaan. Maka dari itu, penelitian yang dilakukan kali ini berbeda dari penelitian sebelum-sebelumnya karena akan menekankan pada segi pencapaian target nasabah laku pandai dan analisa terhadap manfaat dan kendalanya, serta melihat apakah berkontribusi terhadap kinerja perusahaan.

\section{Landasan Teori}

\section{Teori Kontijensi}

Teori kontijensi adalah teori yang menyatakan bahwa tidak ada satu struktur yang cocok untuk semua jenis organisasi (Donaldson, 1999). Agar menjadi efektif, organisasi harus mencocokkan strukturnya dengan faktor-faktor kontijensi, seperti strategi, ukuran, ketidakpastian tugas dan teknologi (Donaldson, 1999). Dalam kaitannya dengan teori kontijensi, tidak tercapainya target nasabah dalam pelaksanaan program laku pandai pada PT XYZ adalah dipengaruhi oleh beberapa faktor. $\mathrm{Di}$ antaranya adalah struktur organisasi PT XYZ yang dikhususkan dalam mengurus program laku pandai dan strategi yang diterapkan dalam pelaksanaan program laku pandai.

Apabila dilihat dari faktor struktur organisasi PT XYZ, yang dikhususkan dalam mengurus program laku pandai ini harusnya bersifat desentralisasi. Hal ini dengan pertimbangan bahwa penyebaran lokasi agen maupun nasabah yang berada di beberapa kabupaten di Indonesia. Dengan struktur organisasi yang bersifat desentralisasi, proses monitoring dan pemeliharaan dalam pelaksanaan program laku pandai ini akan lebih mudah. Keunggulan lainnya dalam penerapan struktur desentralisasi adalah efisiensi waktu dan biaya yang dapat ditekan. Namun dalam praktiknya, PT $X Y Z$ yang dikhususkan dalam mengurus program laku pandai ini bersifat sentralisasi. Seluruh proses monitoring dan pemeliharaan masih dilakukan oleh tim kantor pusat. Dampak yang dirasakan paling tidak efektif adalah diperlukannya waktu yang cukup lama dalam pengiriman dokumen pembukaan rekening nasabah yang kemudian menyebabkan lambatnya proses persetujuan dokumen pembukaan rekening nasabah. Selain itu, pengiriman dokumen tersebut memerlukan biaya dan waktu yang cukup lama.

Strategi yang diterapkan oleh PT XYZ juga dirasakan belum terlalu efektif. Hal ini dikarenakan segmentasi nasabah dari program laku pandai ini adalah hal yang baru bagi PT XYZ yaitu masyarakat yang selama ini belum tersentuh layanan keuangan. Dilihat pada core business dari PT XYZ, segmentasi nasabahnya adalah untuk masyarakat dengan penghasilan menengah hingga atas. Kendala utama yang dirasakan adalah kurangnya pengetahuan dari masyarakat menengah kebawah akan pentingnya dan manfaat dari layanan keuangan. Masyarakat tersebut merasa bahwa pengelolaan keuangan dengan sistem perbankan dirasa belum menjadi suatu kebutuhan, seperti uang menjadi lebih aman, adanya bunga yang dapat diperoleh dari hasil tabungan.

Melihat dari kedua kondisi tersebut, tentunya masih menjadi tugas berat bagi PT XYZ dalam mengelola program laku pandai dengan efektif dan tepat sasaran. Masyarakat yang awalnya tidak mengerti mengenai pentingnya layanan keuangan menjadi masyarakat yang sadar akan transaksi keuangan perbankan.

\section{Kerangka Penelitian}

Kerangka pemikiran dalam penelitian ini adalah sebagai berikut: 


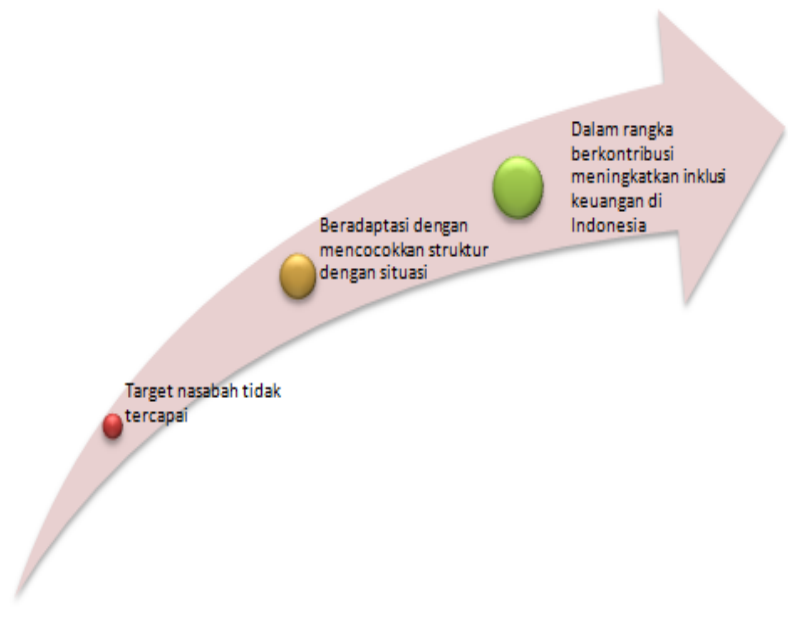

Gambar 4 Kerangka Pemikiran

\section{METODE PENELITIAN}

\section{Studi Kasus}

Penelitian ini adalah penelitian studi kasus. Studi kasus merupakan suatu inkuiri empiris, di mana studi kasus ini meneliti fenomena didalam kehidupan nyata (Yin, 2017). Pertanyaan penelitian pada fenomena yang terjadi pada PT XYZ hanya bisa dijawab melalui studi kasus. Studi kasus membuat peneliti menjadi lebih dalam mengevaluasi keunikan dari pelaksanaan laku pandai pada PT XYZ.

\section{Metode Kualitatif}

Penelitian ini menggunakan metode kualitatif. Metode kualitatif adalah metode yang mengacu pada pengertian yang luas dapat berupa kata-kata tertulis atau lisan dan dapat pula perilaku yang dapat diamati (Taylor, Bogdan, \& DeVault, 2015). Pemilihan metode kualitatif dikarenakan lebih dapat memberikan jawaban terhadap pertanyaan penelitian mengapa target nasabah laku pandai PT XYZ tidak tercapai dan bagaimana pelaksanaan laku pandai pada PT XYZ tersebut. Metode kualitatif ini dilakukan peneliti dalam pengumpulan data karena data yang digunakan dalam menjawab rumusan permasalahan adalah data yang besifat teks, yaitu dalam bentuk wawancara. Dalam pengolahan data, peneliti menggunakan metode kualitatif untuk menganalisa hasil wawancara yang telah didapatkan.

\section{Pengumpulan Data}

Data Primer
Data yang digunakan dalam penelitian ini merupakan data primer yang didapatkan melalui hasil wawancara. Data primer digunakan untuk pemahaman yang lebih baik dalam mendukung jawaban atas pertanyaan penelitian. Data-data primer tersebut berupa wawancara untuk mendapatkan pemahaman mendalam mengenai pelaksanaan laku pandai pada PT XYZ.

\section{Wawancara}

Penelitian ini menggunakan wawancara. Wawancara digunakan dalam penelitian ini karena wawancara didapatkan pemahaman yang lebih mendalam tentang fenomena yang terjadi. Hasil wawancara akan memberikan gambaran umum atas proses yang terjadi pada pelaksanaan laku pandai pada PT XYZ. Akan dilakukan wawancara pada Kepala Biro Inklusi Keuangan, Senior Officer Inklusi Keuangan, Staf Biro Inklusi Keuangan, dan karyawan alih daya Biro Inkkusi Keuangan. Langkah-langkah yang digunakan dalam mengembangkan dan menggunakan wawancara dalam penelitian ini adalah: (Birmingham \& Wilkinson, 2003)
a. Pilot your question
b. Draft the interview
c. Select your interviewees
d. Conduct the interview
e. Analyse the interview data

\section{Analisa Data}

Analisa data penelitian ini dilakukan secara descriptive qualitave analysis. Descriptive qualitave analysis digunakan untuk menjawab pertanyaan penelitian mengapa target nasabah laku pandai PT XYZ tidak tercapai dan bagaimana pelaksanaan Laku pandai pada PT XYZ tersebut. Analisa atas hasil wawancara dilakukan dengan analisis jawaban responden atas pertanyaan yang diberikan. descriptive qualitave analysis yang dilakukan akan mampu memberikan pemahaman mendalam serta dapat mengevaluasi pelaksanaan laku pandai pada PT XYZ dan mengapa target nasabah tidak tercapai sehingga dapat memberikan solusi kepada perusahaan. Akan dilakukan uji validitas dan reliabilitas dalam penelitian ini dan untuk wawancara akan dilakukan pengecekan antar responden serta pengecekan inter-observer.

\section{Unit Analisa}


Unit analisa dalam penelitian ini adalah sebuah bank. Objek penelitian yang dimaksud dalam penelitian ini adalah sebuah perbankan yang beroperasi di Indonesia yaitu PT XYZ yang merupakan salah satu bank pelaksana laku pandai yang memiliki produk laku pandai bernama X. Dipilihnya PT XYZ sebagai unit analisa karena PT XYZ memiliki keunikan sebagai sebuah bank dengan segmen pasar nasabah yang lebih menengah ke atas, namun harus melaksanakan program dengan segmen menengah ke bawah. Ini menarik untuk diteliti. Produk $X$ yang dimiliki PT XYZ dapat membantu masyarakat yang tadinya tidak tersentuh jasa keuangan dapat melakukan transaksi keuangan seperti pada bank tetapi melalui agen. Maka dari itu, unit analisa dalam penelitian ini adalah Biro Inklusi Keuangan PT XYZ untuk dapat menjawab pertanyaan atas masalah penelitian yang ada.

\section{HASIL DAN PEMBAHASAN}

Bab ini membahas mengenai temuan penelitian dan diskusinya untuk membahas pertanyaan penelitian yaitu, pelaksanaan program laku panai PT XYZ; tidak tercapainya target nasabah laku pandai PT XYZ. Proses analisis data diperoleh setelah melakukan wawancara. Penelitian ini menggunakan research instrument yaitu wawancara. Analisa data pada penelitian ini menggunakan descriptive qualitative analysis.

\section{Hasil Temuan}

\section{Wawancara}

Wawancara dilakukan kepada tujuh responden, yaitu dari eselon dua sampai eselon tujuh, serta karyawan alih daya PT XYZ. Analisa terhadap hasil wawancara menggunakan descriptive-qualitative analysis analysis.

Berdasarkan pertanyaan pertama, pelaksanaan laku pandai pada PT XYZ memiliki struktur organisasi sentralisasi. Pelaksanaan laku pandai PT XYZ memiliki proses yang berawal dari nasabah melakukan pembukaan rekening pada agen yang merupakan perpanjangan tangan dari bank. Nasabah yang ingin melakukan pembukaan rekening datang ke agen terdekat lalu mengisi formulir. Selain itu, nasabah melakukan tanda tangan pada formulir pembukaan rekening serta formulir syarat \& ketentuan. Selanjutnya, agen akan meng-input beberapa data pada perangkat agen yang berupa mesin Electronic Data Capture (EDC) android. Selain itu, agen akan melakukan foto diri nasabah, foto KTP, foto formulir, dan foto syarat \& ketentuan menggunakan mesin EDC android tersebut. Lalu, nasabah harus melakukan setoran awal minimal Rp20.000. Selanjutnya setelah di-input maka nasabah akan menerima SMS yang berisi one-time password (OTP), dan dikonfirmasi pada mesin bahwa sudah benar. Formulir pembukaan rekening ini akan dikirim ke PT XYZ melalui mitra. Service level agreement (SLA) Mitra (dari proses pengajuan nasabah sampai pengiriman dokumen) adalah sembilan hari kerja. SLA PT XYZ (dari dokumen diterima sampai pengajuan disetujui) adalah lima hari kerja. Pembukaan rekening ini masih sebagian karena harus melalui proses persetujuan terlebih dahulu. Setelah PT XYZ menerima formulir tersebut, PT XYZ harus mengecek kelengkapan dokumen yang ada. Jika sudah lengkap maka maker akan langsung memproses. Maker akan melakukan pengecekan pengisian formulir pembukaan rekening apakah sudah sesuai atau belum dengan KTP. Selain itu, maker juga melakukan pengecekan apakah calon nasabah memiliki rekening lain pada bank tersebut. Selain itu, maker juga melakukan pengecekan data nasabah pada dukcapil. Jika sudah sesuai dan tidak memiliki rekening lain, maka akan di-input pada backoffice data-data lain yang tidak di-input oleh agen pada mesin EDC tadi. Jika nasabah memiliki rekening lain dan juga data tidak sesuai dengan dukcapil, maka akan ditolak. Persetujuan atau penolakan formulir pembukaan tersebut dilakukan oleh approver. Keseluruhan pelaksanaan ini tidak melibatkan kantor cabang bank. Jadi semua formulir dari seluruh kabupaten/kota masuk ke Biro Inklusi Keuangan. Berikut adalah kutipan dari wawancara yang dilakukan mengenai hal tersebut:

“... karena PT XYZ tidak bisa berinteraksi langsung ke mereka ataupun cabang-cabang kita, jadi tidak melibatkan cabang. ...." (Responden 3, 2019)

Pelaksanaan laku pandai pada PT XYZ juga memerlukan investasi yang tinggi. Investaasi ini dikeluarkan untuk mesin EDC dan kegiatan operasional laku pandai. Berikut adalah kutipan dari wawancara yang dilakukan mengenai hal tersebut:

"...salah satu hal yang bisa saya sampaikan ada jadi dari sisi investasi, investasi ini sendiri adalah jika kita berbicara mengenai biaya 
yang dikeluarkan biaya yang dikeluarkan itu kan terkait dengan biaya keseharian atau biaya operasional yang dikeluarkan atau harus disediakan oleh bank itu sendiri, lalu kemudian terkait dengan logistik terkait dengan device atau perangkat yang digunakan biaya untuk keseharian yang memang harus kita bayarkan kepada agen termasuk seperti komisi termasuk imbalan yang memang harus diterima oleh agen ...." (Responden 5, 2019)

“... karena pengeluaran kita untuk investasi ini sangat besar dibanding dengan pemasukan jadi untuk jangka pendek belum menguntungkan." (Responden 6, 2019)

Selain hal tersebut di atas, proses pelaksanaan pembukaan rekening laku pandai masih belum efisien. Formulir pembukaan rekening nasabah laku pandai yang dikirimkan ke tim kantor pusat akan di-input kelengkapan datanya oleh maker, namun masih terdapat proses yang sangat manual dalam pengecekan Know Your Customer (KYC). KYC nasabah yang berupa pengecekan identitas nasabah pada aplikasi Kependudukan dan Pencatatan Sipil (Dukcapil) serta pengecekkan apakah telah memiliki rekening bank. Proses pembukaan rekening nasabah juga melebihi SLA yang ada. Berikut adalah kutipan dari wawancara yang dilakukan mengenai hal tersebut:

"... di kita manual dari nasabah buka sampai approved bisa dua tiga bulan,..." (Responden $4,2019)$

"kalau SLA pembukaan rekening nasabah itu 7 hari kerja dan juga untuk pembukaan agen baru itu 14 hari kerja tapi yang terjadi saat ini di nasabah sendiri SLA sekitar dua mingguan jadi 14 hari kerja jadi kita telat selama 7 hari ini dikarenakan tumpukan pembukaan rekening nasabah yang cukup banyak ..." (Responden 7, 2019)

Fitur yang ada pada laku pandai PT XYZ hanya sebatas setoran, tarikan, dan transfer antar rekening laku pandai saja. Namun, saat ini sedang dikembangkan fitur lainnya berupa pembelian pulsa dan pembayaran BPJS. PT XYZ belum masuk sampai pinjaman dan asuransi karena dari tabungan ingin mengumpulkan database terlebih dahulu untuk mengetahui perilaku kustomernya. Sehingga nantinya akan diketahui kemampuan bayar mereka seperti apa. Berikut adalah kutipan dari wawancara yang dilakukan mengenai hal tersebut:

"... di tahun 2019 ini kita akan tambahkan fitur-fitur yang lain seperti pembelian pulsa atau pembayaran-pembayaran yang lain, ..." (Responden 2, 2019)

"... di tahun ini fokus kita adalah untuk mengcreate fitur-fitur baru dan meningkatkan kualitas agen, ..." (Responden 3, 2019)

Berdasarkan pertanyaan kedua, target nasabah laku pandai tidak tercapai. karena kurangnya pengalaman yang dimiliki PT XYZ dalam menangani segmen pasar laku pandai. PT XYZ selama ini merupakan perusahaan dengan segmen nasabah menengah ke atas, maka untuk laku pandai ini sendiri adalah hal baru bagi PT XYZ. Berikut adalah kutipan dari wawancara yang dilakukan mengenai hal tersebut:

"... masih belum tersosialisasi dengan baik untuk hal-hal yang bersifat keuangan, institusi keuangan buat mereka adalah suatu hal yang resmi yang buat buat mereka jadi takut untuk masuk dalam itu ini yang mungkin jadi kendala kita bagaimana supaya mereka benar-benar jadi percaya dan tidak takut untuk melakukan transaksi-transaksi dengan perbankan, ...." (Responden 1, 2019)

"... Secara unit kerja itu jadi tidak tercapai karena di tahun 2018 itu kan tahun transisi, sebelumnya mulainya laku pandai itu di tahun 2015, dari 2015 itu kita bekerjasama dengan pihak ketiga sampai dengan tahun 2017 akhir, karena dari evaluasi yang kita lihat itu kerjasama dengan pihak ketiga tersebut kurang efektif ... Kemudian juga waktu itu dari sisi pemasaran kita serahkan dengan pihak ketiga tersebut. ..., makanya dari itu kita lakukan evaluasi dan akhirnya diputuskan perusahaan mengembangkan sistem sendiri. ...." (Responden 2, 2019)

"... di mana sebelumnya kita outsource ke pihak ketiga yang namanya $X$, di tahun 2018 manajemen memutuskan untuk ... 
dikembangkan secara privat oleh PT XYZ, dengan demikian tahun 2018 kita fokus ke proses transisi. ... kita mempersiapkan migrasi dulu dari sistem lama ke sistem baru yaitu kita lakukan di kuartal pertama 2018 di mana pada saat proses itu tentunya kegiatan di lapangan tidak bisa settle atau running sesuai dengan yang diharapkan. Berjalannya waktu kita migrasi di kuartal pertama, pada saat prosesnya berjalannya waktu beberapa kendala sistem itu yang tidak kita prediksi terjadi seperti masalah-masalah komunikasi ya masalah komunikasi di device kita, di mana setiap kali dial, timeout, dial timeout, terjadinya timeout itu sangat sangat mengganggu proses pembukaan rekening ..." (Responden 3, 2019)

"Faktor dari pemerintah dan regulator kurang support, ...kenapa saya bilang pemerintah dan regulator kurang support, mereka lempar ke pelaku usaha dalam hal ini bank dan juga fintech dan juga TELCO untuk cari mekanisme masing-masing gitu loh, harusnya kan mereka support juga melalui pemda-pemda, melalui sosialisasi support atau apa. ... Nah kalau dari internal menurut saya sih perusahaan ini masih melihat wait and see kebijakan pemerintah tuh seperti apa apakah ini mau dilanjutkan untuk jangka panjang atau cuma comply ..." (responden 4, 2019)

"...kalau kita lihat dari faktor penyebabnya itu bisa disebabkan oleh beberapa hal ya yang pertama mungkin yang paling jelas itu adalah kalau kita berbicara mengenai produk laku ini sendiri ini kan adalah suatu produk yang baru tentunya bukan suatu hal yang mudah bagi suatu Bank atau perusahaan dalam menggarap suatu hal yang baru karena di sini kan kita punya kendala terkait dengan segmentasi pasar yang harus kita sasar gitu ya, ...yang kedua adalah untuk masalah edukasi tentunya adalah untuk masyarakat masyarakat pedesaan yang sebelumnya belum mengerti apakah itu yang dinamakan untuk layanan keuangan tentunya membuat mereka untuk percaya membuka rekening ...." (Responden 5, 2019)

\section{Diskusi}

\section{Pelaksanaan Laku Pandai PT XYZ}

Pelaksanaan laku pandai pada PT XYZ memiliki struktur organisasi sentralisasi. Kelemahan dari tidak melibatkan cabang adalah biaya menjadi tinggi karena tidak memanfaatkan infrastruktur yang sudah ada. Dengan di kelolanya operasional pada kantor pusat menyebabkan PT XYZ harus bekerjasama dengan mitra untuk memaintain agen. Ini menyebabkan biaya yang tinggi karena harus membayar mitra. Selain itu juga biaya tinggi disebabkan perlunya sumber daya manusia baru dan sistem yang baru.

Dengan tidak melibatkan cabang maka biaya dari pelaksanaan laku pandai ini sendiri menjadi tinggi. Hal tersebut sesuai dengan teori kontijensi, di mana teori kontijensi menyatakan bahwa tidak ada satu struktur yang cocok untuk semua jenis organisasi (Donaldson, 1999). Agar menjadi efektif, organisasi harus mencocokkan strukturnya dengan faktor-faktor kontijensi, seperti strategi, ukuran, ketidakpastian tugas dan teknologi (Donaldson, 1999). PT XYZ seharusnya mencocokkan strukturnya dengan faktor-faktor seperti persebaran agen dan nasabah. Persebaran agen dan nasabah PT XYZ berada di beberapa kabupaten dan kota di Indonesia. Namun dalam praktiknya, PT XYZ yang dikhususkan dalam mengurus program laku pandai ini bersifat sentralisasi.

Pelaksanaan laku pandai PT XYZ yaitu proses monitoring dan pemeliharaannya masih dilakukan oleh tim kantor pusat. Dampak yang dirasakan paling tidak efektif adalah diperlukannya waktu yang cukup lama dalam pengiriman dokumen pembukaan rekening nasabah yang kemudian menyebabkan lambatnya proses persetujuan dokumen pembukaan rekening nasabah. Selain itu, pengiriman dokumen tersebut memerlukan biaya dan waktu yang cukup lama.Dengan struktur organisasi yang melibatkan cabang bank, proses monitoring dan pemeliharaan dalam pelaksanaan program laku pandai ini akan lebih mudah. Keunggulan lainnya adalah efisiensi waktu dan biaya yang dapat ditekan.

Laku pandai PT XYZ membutuhkan investasi yang mahal pada pengadaan perangkat agen,investasi pada mesin EDC android terbilang cukup mahal. Mesin EDC android lebih mahal dari mesin EDC yang ada di merchant. PT XYZ dapat menggunakan alternatif lain berupa penggunaan aplikasi secara digital. Selain itu dapat 
meminimalkan penggunaan kertas dengan menggunaakn formulir digital.

Proses pelaksanaan pembukaan rekening laku pandai masih belum efisien. PT XYZ dapat menggunakan sistem yang terintegrasi dan tidak manual dalam pengecekkan hal tersebut. Jadi, ketika data nasabah di-input oleh agen seharusnya ketika masuk ke maker sudah langsung terdeteksi apakah nasabah dengan data tersebut memiliki rekening lain, ataupun data tidak sesuai dengan data dukcapil. Tentunya ini akan mempercepat proses penerimaan nasabah.

Laku pandai PT XYZ memiliki keterbatasan fitur. Fitur yang ada pada laku pandai PT XYZ hanya sebatas setoran, tarikan, dan transfer antar rekening laku pandai saja. Namun, saat ini sedang dikembangkan fitur lainnya berupa pembelian pulsa dan pembayaran BPJS. PT XYZ belum masuk sampai pinjaman dan asuransi karena dari tabungan ingin mengumpulkan database terlebih dahulu untuk mengetahui perilaku kustomernya. Sehingga nantinya akan diketahui kemampuan bayar mereka seperti apa. Menurut Soejachmoen (2016) terdapat langkah-langkah intervensi dalam inklusi keuangan. Yang pertama adalah kesadaran dari masyarakat. Setelah masyarakat memiliki pengetahuan dan kesadaran yang cukup, langkah berikutnya adalah pembayaran, penyimpanan, kredit, dan asuransi. PT XYZ telah melakukan program literasi keuangan dengan melakukan edukasi baik ke masyarakat desa maupun calon agen. Hal ini membuat kesadaran masyarakat akan layanan keuangan meningkat. Selain itu, laku pandai PT XYZ juga sudah dapat melakukan aktivitas menabung. Untuk pembayaran, saat ini masih dikembangkan oleh PT XYZ. Dengan fitur yang masih sedikit maka kurang menarik minat masyarakat untuk melakukan pembukaan rekening. PT XYZ dapat menambah fitur pinjaman dan asuransi, agar banyak masyarakat yang berminat melakukan pembukaan rekening laku pandai PT $X Y Z$, sehingga nantinya masyarakat semakin inklusif dan kesejahteraan adapt meningkat.

\section{Tidak Tercapainya Target Nasabah Laku Pandai PT XYZ}

Target nasabah laku pandai tidak tercapai karena kurangnya pengalaman yang dimiliki PT XYZ dalam menangani segmen pasar laku pandai ini. PT XYZ selama ini merupakan perusahaan dengan segmen nasabah menengah ke atas, maka untuk laku pandai ini sendiri adalah hal baru bagi PT XYZ

Pada tahun 2018 juga terdapat migrasi sistem, yang dulunya menggunakan pihak ketiga dari India. Namun, pada tahun 2018 menggunakan sistem yang dibangun sendiri. Hal ini terjadi karena selama bekerja sama dari tahun 2015 sampai dengan tahun 2017 kerjasama dengan pihak ketiga tersebut kurang efektif. Pihak ketiga tersebut memiliki pengalaman di India dan berhasil, namun karakter masyarakat Indonesia tidak sama seperti di India. Hal ini yang menyebabkan kurang berhasilnya laku pandai PT XYZ. Sehingga, pada tahun 2018 terdapat peralihan sistem yang masih belum stabil. Sering dijumpai pada lapangan masalah mesin yang tidak dapat digunakan. Ini yang menyebabkan pembukaan rekening nasabah terhambat.

Tidak tercapainya target nasabah juga karena proses yang melebihi SLA. SLA Mitra (dari proses pengajuan nasabah sampai pengiriman dokumen) adalah sembilan hari kerja. SLA PT XYZ (dari dokumen diterima sampai pengajuan disetujui) adalah lima hari kerja. Ketika proses pembukaan rekening melebihi SLA, maka banyak nasabah yang lama menunggu proses persetujuan. Dengan belumnya disetujui pembukaan rekening tersebut, maka nasabah hanya bisa melakukan setoran dan menerima transfer dari sesama rekening laku pandai PT XYZ. Ketika nasabah membutuhkan dana nasabah tidak dapat melakukan tarikan, sehingga nasabah akan melakukan tutup rekening untuk mengambil dananya. Lamanya proses persetujuan rekening ini terkait dengan proses yang masih manual dan tidak terintegrasi antara pengecekan data nasabah dengan data dukcapil, serta pengecekan kepemilikan rekening lain nasabah.

PT XYZ masih belum memiliki pengalaman dalam segmen laku pandai dan ada di tahap yang masih belajar. Proses migrasi sistem yang ada dan proses pembukaan rekening yang melebihi SLA membuat target nasabah tidak tercapai. Ini karena PT XYZ tidak memiliki pengalaman dan masih belajar dalam segmen pasar ini.

Dalam melaksanakan laku pandai ini PT XYZ sudah mulai dari tahun 2015. Ini artinya sudah tiga tahun PT XYZ berkecimpung disini. 
Seiring berjalannya waktu pasti sudah terdapat pengalaman dan pembelajaran yang didapat agar proses didalam laku pandai ini menjadi lebih efisien.

\section{KESIMPULAN}

Bab ini ditulis dalam rangka menjawab pertanyaan penelitian mengapa target nasabah laku pandai PT XYZ tidak tercapai dan bagaimana pelaksanaan laku pandai pada PT XYZ tersebut. Pada bab ini akan dibahas mengenai ringkasan penelitian, keterbatasan penelitian, dan usulan penelitian selanjutnya. Pelaksanaan laku pandai PT XYZ menunjukkan pencapaian nasabah laku pandai yang tidak sesuai dengan yang ditargetkan pada tahun 2018.

Berdasarkan permasalahan tersebut, maka tujuan penelitian adalah untuk mengevaluasi pelaksanaan laku pandai di PT XYZ dan menganalisa faktor-faktor yang menyebabkan target nasabah laku pandai tidak tercapai pada tahun 2018. Temuan dalam penelitian ini menunjukkan bahwa, (1) Pelaksanaan laku pandai PT XYZ menggunakan struktur yang tersentralisasi atau tidak melibatkan cabang. Dengan tidak melibatkan cabang maka semua proses dilakukan oleh tim kantor pusat dan biaya yang dikeluarkan menjadi tinggi. (2) Pelaksanaan laku pandai PT XYZ membutuhkan investasi yang tinggi pada pengadaan perangkat agen yang berupa mesin EDC android. (3) Pelaksanaan laku pandai PT XYZ masih belum terintegrasi, ini dilihat dari masih manualnya pengecekkan data nasabah pada aplikasi dukcapil dan pengecekkan mengenai kepemilikan rekening lain oleh nasabah. Hak tersebut membuat proses penerimaan nasabah menjadi lama. (4) Pelaksanaan laku pandai PT XYZ masih memiliki fitur yang terbatas pada setoran, tarikan, dan transfer antar rekening laku pandai. Dengan fitur yang masih sedikit maka kurang menarik minat masyarakat untuk melakukan pembukaan rekening. (5) PT XYZ kurang memiliki pengalaman dalam menangani segmen pasar laku pandai. Hal ini menyebabkan tidak tercapainya target nasabah laku pandai PT XYZ. Selain itu, selama pelaksanaan laku pandai PT XYZ terdapat peralihan sistem, dan diawal masih belum stabil. Hal tersebut juga menyebabkan target nasabah tidak tercapai. (6) Proses pembukaan rekening nasabah laku pandai PT XYZ memerlukan waktu yang melebihi SLA. Lamanya proses persetujuan rekening ini terkait dengan proses yang masih manual dan tidak terintegrasi. Hal ini juga membuat target nasabah laku pandai PT XYZ tidak tercapai.

Dapat disimpulkan bahwa laku pandai PT XYZ masih belum terlaksana dengan baik membuat target nasabah tahun 2018 tidak tercapai. Laku pandai adalah satu segmen baru bagi PT XYZ yang dalam pelaksanaannya masih terus melakukan proses pembelajaran. Pemilihan struktur organisasi masih belum tepat karena terlaksana secara sentralisasi. Hal tersebut sesuai dengan teori kontijensi yang menyatakan bahwa tidak ada satu struktur yang cocok untuk semua jenis organisasi (Donaldson, 1999). Agar menjadi efektif, organisasi harus mencocokkan strukturnya dengan faktor-faktor kontijensi, seperti strategi, ukuran, ketidakpastian tugas dan teknologi (Donaldson, 1999). PT XYZ seharusnya mencocokkan strukturnya dengan faktor-faktor seperti persebaran agen dan nasabah. PT XYZ diharapkan dapat melibatkan cabang bank dalam pelaksanaan laku pandai ini sendiri. Selain itu, PT XYZ dapat melakukan simplifikasi proses secara otomatisasi untuk membuat proses pelaksanaan laku pandai menjadi lebih efisien. PT XYZ juga dapat menggunakan aplikasi digital sehingga tidak perlu investasi besar pada mesin EDC android. Selain itu PT XYZ harus menambah fiturfitur lain seperti pinjaman dan asuransi untuk menarik nasabah baru.

Keterbatasan penelitian ini adalah dari cakupannya hanya satu bank yaitu PT XYZ. Selain itu, keterbatasan penelitian lainnya hanya melihat dari sisi perusahaan saja, tidak melihat dari sisi pemerintah, regulator, agen, dan nasabah.

\section{REKOMENDASI}

PT XYZ diharapkan dapat melibatkan cabang bank dalam pelaksanaan laku pandai ini sendiri. Selain itu, PT XYZ dapat melakukan simplifikasi proses secara otomatisasi untuk membuat proses pelaksanaan laku pandai menjadi lebih efisien. PT XYZ juga dapat menggunakan aplikasi digital sehingga tidak perlu investasi besar pada mesin EDC android. Selain itu PT XYZ harus menambah fitur-fitur lain seperti pinjaman dan asuransi untuk menarik nasabah baru. Penelitian selanjutnya diharapkan dapat memperluas cakupannya dengan memperbanyak bank yang di teliti. Selain itu, penelitian 
selanjutnya juga diharapkan melihat pelaksanaan laku pandai dari sisi pemerintah, regulator, agen, dan nasabah.

\section{DAFTAR PUSTAKA}

Abdullah, T. (2014). Bank dan Lembaga Keuangan.

Birmingham, P., \& Wilkinson, D. (2003). Using research instruments: $A$ guide for researchers. Routledge.

Cahyaningrum, D. (2017). Perlindungan Nasabah dalam Penyelenggaraan Laku Pandai BCA di Jawa Tengah dan BRI di Papua (Customer Protections in "Laku Pandai" Implementation: Study of BCA "Laku Pandai: Consumer Protection in Middle Java and BRI). Negara Hukum: Membangun Hukum Untuk Keadilan Dan Kesejahteraan, 7(2), 213-234.

Chipeta, C., \& Muthinja, M. M. (2018). Financial innovations and bank performance in Kenya: Evidence from branchless banking models. South African Journal of Economic and Management Sciences (Vol. 21). AOSIS Publishing.

Donaldson, L. (1999). The normal science of structural contingency theory. Studying Organizations: Theory and Method. Thousand Oaks, Calif: Sage, 51-70.

Ellet, W. (2007). The case study handbook: How to read, discuss, and write persuasively about cases. Harvard Business Press.

Bank Indonesia. (2013). Layanan Perbankan Tanpa Kantor. Gerai Info Bank Indonesia.

Bank Indonesia. (2014). Booklet Keuangan Inklusif Bank Indonesia. Tersedia Pada Http://Www. Bi. Go. Id/Id/Perbankan/Keuanganinklusif/Edukasi/ Contents/Buku Saku Keuangan\% O20Inklusif. Pdf,(25.09. 2017).

Peraturan Presiden Republik Indonesia. (2016). Peraturan Presiden Republik Indonesia Nomor 82 Tahun 2016 tentang Strategi Nasional Keuangan Inklusif.

Otoritas Jasa Keuangan. (2016). Peraturan Otoritas Jasa Keuangan No 76 Tahun 2016 tentang Peningkatan Literasi Dan Inklusi Keuangan Di Sektor Jasa Keuangan Untuk Konsumen Dan/Atau Masyarakat. Jakarta: OJK.
Kipng'etich, B. R., Chepkilot, R. K., \& Koima, J. (2018). Cost of Banking Transactions Through Agency Banking As a Competitive Strategy: a Case of Kenya Commercial Bank in Nakuru County, Kenya. International Journal of Business and Processes, 3(3), 7.

Levine, R. (2002). Bank-based or market-based financial systems: which is better? Journal of Financial Intermediation, 11(4), 398-428.

Sanjaya, I. M. (2016). Inklusi Keuangan dan Pertumbuhan Inklusif: Analisis Antar Provisni di Indonesia1. Buletin Ekonomi Moneter dan Perbankan, 281.

Shihadeh, F. H., Hannon, A. (M. T. ., Guan, J., Haq, I. ul, \& Wang, X. (2018). Does Financial Inclusion Improve the Banks' Performance? Evidence from Jordan (pp. 117-138). https://doi.org/10.1108/S0196382120170000034005

Soejachmoen, M. P. (2016.). Financial Inclusion in Indonesia - What We Can do More. http://paradigmaekonomi.org

Syaniardi, Y. H., \& Shihab, M. R. (2016). Formulating e-business strategy for branchless banking: A case of a bank in Indonesia. In 2016 International Conference on Advanced Computer Science and Information Systems (ICACSIS) (pp. 201206). IEEE.

Taylor, S. J., Bogdan, R., \& DeVault, M. (2015). Introduction to qualitative research methods: A guidebook and resource. John Wiley \& Sons.

Wibowo, M. Y. P., \& Muharrami, R. S. (2018). Pengaruh Literasi Keuangan dan Akses Terhadap Keputusan Berinvestaasi di Pasa Modal Syariah (Studi Kasus: Investor di Galeri Investasi Bursa Efek Indonesia Fakultas Ekonomi dan Bisnis Islam IAIN Surakarta). IAIN Surakarta.

Yin, R. K. (2017). Case study research and applications: Design and methods. Sage publications.

http://www.ojk.go.id/id/Pages/Laku-Pandai.aspx (Diakses pada: Sabtu, 16 Februari 2019).

https://www.ojk.go.id/id/kanal/pasarmodal/data-dan-statistik/statistik-pasarmodal/Documents/4.\%20Statistik\%20Dese mber\%20Mgg\%20ke-4\%202018.pdf (Diakses pada: Minggu, 24 Februari 2019) 
https://www.idx.co.id/perusahaan-

tercatat/profil-perusahaan-tercatat/

(Diakses pada: Minggu, 24 Februari 2019)

https://www.ojk.go.id/id/kanal/perbankan/data

-dan-statistik/statistik-perbankan-

indonesia/Documents/Pages/Statistik-

Perbankan-Indonesia---Desember-

2018/SPI\%20Desember\%202018.pdf

(Diakses pada: Minggu, 24 Februari 2019) 